\title{
TEORII DESPRE DREPTUL NATURAL ÎN \\ ANTICHITATE ȘI EVUL MEDIU
}

DOI: 10.24193 /SUBBiur.65(2020).4.16

Data publicării online:

15.03 .2021

Arthur MIHĂILĂ*

Rezumat: Filosofii dreptului natural credeau că legile omenești trebuie să fie determinate de principii morale ale căror origini trebuiau să se regăsească în natura umană sau în voința lui Dumnezeu. În acest articol, vom analiza cele mai importante teorii ale dreptului natural din Antichitate și până în Evul Mediu. Tradiția dreptului natural își are originea în filosofia lui Platon, Aristotel, Cicero a Sfântului Augustin și a lui Toma din Aquino. Această filosofie a fost resuscitată după Holocaust, în secolul XX, fiind influentă și în ziua de azi.

Cuvinte cheie: drept natural, natura omenească, jurisprudență, Holocaust, Aristotel, Toma d'Aquino.

\section{NATURAL LAWS THEORIES IN ANTIQUITY AND MIDDLE AGES}

Abstract: Natural law philosophers believe that human laws must be defined by moral principles that have origins in human nature or the will of God. In this paper the author analyzes the most important natural law theories from Antiquity and

* Lector dr. la Sociologia dreptului, Filosofia dreptului şi Logică juridică, UBB Cluj-Napoca arthurmihaila@yahoo.co.uk. 
Middle Ages. Natural law tradition has its roots in the philosophy of Plato, Aristotle, Cicero, Saint Augustine and Thomas Aquinas. That philosophy was resuscitated in the twentieth century after the Holocaust and continues to be influential to the present day.

Keywords: natural law, human nature, jurisprudence, Holocaust, Aristotle, Thomas Aquinas.

\section{Cuprins}

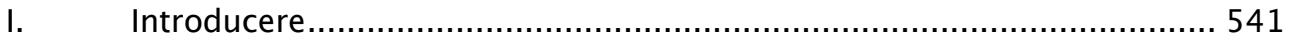

II. Filosofia dreptului natural în Antichitate: Platon, Aristotel, Cicero......... 543

III. Filosofia dreptului natural în Evul Mediu : Sfântul Augustin, Albertus Magnus, Toma din Aquino, școala de la Salamanca. .............................................. 552

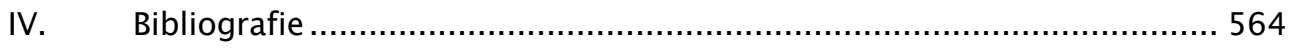

\section{Introducere}

La sfârşitul celui de-al Doilea Război Mondial, procurorii și judecătorii de la Nuremberg au fost puşi în fața unei dileme: cum poți acuza şi condamna membri ai administrației și cadre militare dacă aceștia au executat ordinele superiorilor sau au pus în aplicare legea germană. Din perspectiva pozitivismului, filosofia juridică dominantă la începutul secolului XX, aceste persoane erau nevinovate, chiar dacă se implicaseră într-un genocid și săvârșiseră un număr impresionant de atrocități, pentru că nu încălcaseră nici legea națională și nici un tratat internațional. Judecătorii de la Nuremberg au 
putut ieși din impas recurgând la o filosofie juridică ce căzuse cu câteva sute de ani în urmă în desuetudine, filosofia dreptului natural' ${ }^{1}$.

Încă din perioada revoluției franceze dreptul natural a fost abandonat ca temei al validității legilor în favoarea teoriei contractualiste ce a făcut apoi loc utilitarismului, realismului juridic şi pozitivismului. Toate aceste filosofii şi doctrine juridice respingeau ideea unei legături organice între morală şi lege. Momentul Nuremberg a marcat resuscitarea acestei filosofii și apariția unei noi școli a dreptului natural. $\mathrm{Cu}$ toate acestea, cu unele excepții ${ }^{2}$, noii reprezentanți ai dreptului natural nu au adus ceva nou ci şi-au îndreptat privirea spre cel mai important reprezentant clasic al dreptului natural -

${ }^{1}$ În pledoaria introductivă a Procesului de la Nuremberg, procurorul șef american Robert H. Jackson (Jackson, Robert H., "Opening Adress for the U.S., Nuremberg Trials" în Adams, David M., Philosophical Problems in the Law, Boston: Wadsworth Cengage Learning, 2012, pp. 23-28) nu folosește termenul de drept natural dar susţine că faptele invocate sunt condamnabile moral și atât de neetice încât prin natura lor sunt ilegale chiar dacă legea locală nu le condamnă. În plus „Crimele pe care încercăm să le condamnăm și să le pedepsim au fost atât de calculate, atât de maligne și atât de devastatoare încât civilizația nu poate tolera ca ele să fie repetate”. Jackson susținea că vina acuzaților nu trebuie să fie stabilită plecând de la faptul că au încălcat prevederile unor convenții internaționale ci pe baza faptului că au planificat și săvârșit sau au intenționat să săvârșească atât crime legale cât și unele morale. Se cuvine să amintim faptul că în momentul respectiv au existat și autori care au criticat decizia completului de la Nuremberg de a invoca dreptul natural pentru a condamna persone vinovate de „crime împotriva umanității”. De pildă judecătorul Charles E. Wyzanski Jr. (Wyzanski Jr., Charles E., "Nuremberg: A Fair Trial?” în Adams, David M., Philosophical Problems in the Law, Boston: Wadsworth Cengage Learning, 2012, pp. 29-34) considera că decizia de la Nuremberg încalcă unele principii juridice cum ar fi ex post facto. El era de părere că nu pot fi justificate decât deciziile luate împotriva germanilor care au ucis persoane aflate pe teritoriul altor state, pentru că în cazul acesta puteau fi invocate articolele 46 și 47 ale convenției de la Haga la care Germania a aderat în 1907. Wyzanski observa că nu există nici o prevedere întrun tratat internațional care să interzică unui stat să își omoare sau să își tortureze propriii cetățeni și din această cauză nu pot fi pedepsiți cetățenii germani care au ucis evrei germani sau alți non-naziști, pe teritoriul Germaniei între 1933 și 1945.

${ }^{2}$ Cel mai original reprezentant al noului drept natural este John Finnis. Chiar dacă a plecat tot de la tezele lui Toma din Acquino, Finnis a eliminat elementele desuete din filosofia tomistă și a oferit o nouă perspectivă care corespunde filosofiei drepturilor omului din secolul XX. 
Toma din Aquino, dezvoltând ideile sale. Din această cauză acești filosofi au fost denumiți de unii autori „neotomişti”. Teoria clasică a dreptului natural a fost invocată pentru a justifica sentințe date în cazurile lui Adolf Eichman, a genocidului din Rwanda şi a crimelor din timpul războiului din Yugoslavia, și probabil va sta la baza sentințelor date în cazul altor crime săvârșite în războaiele civile. Importanța pe care o au în momentul de față tezele dreptului natural dezvoltate în Antichitate și Evul Mediu justifică examinarea lor în detaliu pe parcursul acestui studiu.

II. Filosofia dreptului natural în Antichitate: Platon, Aristotel, Cicero.

Aristotel este cel care e considerat a fi părintele filosofiei dreptului natural. $\mathrm{Cu}$ toate acestea și înainte de el întâlnim sporadic ideea că legile morale prevalează uneori în fața dreptului pozitiv.

Pentru prima dată întâlnim această idee în Antigona lui Sofocle. Piesa de teatru este situată în Teba. Înainte de întâmplările relatate a avut loc un război civil între frații Antigonei, Eteocles și Polynices, fiii fostului rege Oedip, care doreau amândoi tronul și care au murit în timpul luptei. Înainte de război, Polynices fusese exilat dar a hotărât să se întoarcă în Teba și să își înfrunte fratele. Pentru că s-a întors din exil, nesocotind pedeapsa, și pentru că a provocat războiul, noul rege al Tebei, Creon, a proclamat printr-un decret că Polynices nu va fi îngropat ci corpul său va fi lăsat să fie sfârtecat de câini şi păsări. Încălcând decretul regal, Antigona hotărăște să își îngroape fratele, dar este surprinsă de gărzi în timp ce îndeplinea ceremoniile funerare. Întrebată de ce a încălcat legea îngropându-și fratele Antigona răspunde: „Nu 
Zeus a dat această proclamație/ Pentru mine; nici Dike3, care stă/ În aceeași casă cu zeii subpământeni/ Nu a dat oamenilor legi ca ale tale./Nu cred că proclamația ta este atât de puternică/ Încât tu, un muritor, ai putea anula legile,/ Zeilor, care sunt nescrise și infailibile./Pentru că aceste legi nu există de azi sau ieri/ Ci dintotdeauna, și nimeni nu știe cu cât timp în urmă/Au apărut. Si de aceea nu intenționez/Să fiu pedepsită de zei/Pentru că am fost înfricoşată de voința unui om.”4

În acest pasaj Sofocle, prin gura Antigonei, exprimă opinia că legile pozitive trebuie să respecte unele legi morale care sunt nescrise și infailibile, dar care sunt cunoscute de toată lumea. Din fragment se subînțelege că atunci când legile pozitive încalcă aceste legi care există dintotdeauna, cetățenii trebuie să respecte legea morală şi nu legea pozitivă.

Expresiile „drept natural” şi „lege proprie naturii” pot fi întâlnite la Platon în dialogul Gorgias, 483-484. În acestă parte a dialogului Callicles argumentează că dreptul natural este dreptul celui mai puternic, pentru că în natură cel mai puternic se impune în fața celui mai slab. Callicles este de părere că legile au fost statornicite de oamenii slabi şi mulți pentru a-i controla pe cei puternici și pentru a obține avantaje. În natură însă se impun cei mai capabili și cei mai puternici. O opinie asemănătoare o întâlnim și în Republica atunci când Trasimachos argumenta că dreptul este folosul celui mai puternic (Republica, 338c). Socrate nu este de acord cu opinia lui Callicles. El folosește chiar argumentul lui Callicles pentru a dovedi că dreptul nu poate fi confundat cu puterea. Un grup de oameni este mai puternic decât un individ aşa încât dacă am considera că dreptul natural constă în legile

\footnotetext{
3 Zeița justiției.

4 Sophocles, Antigone, Oxford: Oxford University Press, 2003, p. 73 (450-459).
}

\section{4}


impuse de cel mai puternic atunci trebuie să acceptăm și ideea că legile votate de majoritate, care este mai puternică din punct de vedere fizic, sunt legi naturale. În continuarea dialogului Socrate își expune propria opinie: dreptul natural este cel impus de oamenii buni și are drept rezultat legi bune pentru cetate. Rezultă că dreptul natural este cel care aduce un folos cetățenilor și nu persoanelor care promulgă legile şi care contribuie la impunerea dreptății și a celorlalte virtuți.

În ultimul său dialog, Legile, Platon încearcă să ofere un model de legislație pentru cetate. De data aceasta nu este un model utopic şi greu de pus în practică, la fel ca cel din Republica, ci este un model care putea fi aplicat în Atena contemporană lui. Unii autori sunt de părere că Platon a scris acest dialog atunci când membrii Academiei au fost solicitați să elaboreze legi pentru cetate 5 în scopul de a oferi un îndrumar pentru discipolii săi care ar fi acceptat această sarcină. Aflat la o vârstă înaintată, Platon a refuzat oferta dar s-a simțit obligat să își spună părerea cu privire la un sistem legislativ optim și la modul în care trebuie elaborată o lege.

În Legile, Platon afirmă că scopul legii este de a dezvolta virtuţile în rândul cetățenilor şi de a promova armonia și pacea în cetate. În aceast scop legile trebuie să procure două tipuri de bunuri, unele omenești și altele divine $^{6}$, care se completează unele pe altele. Cele omenești sunt sănătatea, frumusețea, puterea (pentru alergări sau alte exerciții) și averea însoțită de buna judecată. Bunurile divine sunt buna judecată, autocontrolul care folosește rațiunea, iar din combinația primelor două bunuri divine cu curajul rezultă al treilea bun - justiția. Curajul simplu se situează pe locul patru între

\footnotetext{
5 Reale, Giovanni, Istoria filosofiei antice, vol 3: Platon şi Academia antică, Târgu Lăpuș: Galaxia Gutenberg, 2009, p. 371.

6 Plato, The Laws, Harmondsworth: Penguin Books, 1970, p,55. (633).
}

\section{5}


bunurile divine. Bunurile divine sunt de fapt virtuți care contribuie la dezvoltarea bunurilor omenești. Pentru a fi eficiente legile trebuie să aibă şi un element persuasiv. Din această cauză legile trebuie să conțină și un preambul care are drept scop să îi convingă pe cetățeni de necesitatea punerii în aplicare a normelor cuprinse în lege. Concepția lui Platon cu privire la „bunurile” esențiale care trebuie să fie promovate şi ocrotite de legi a fost însuşită de un adept contemporan al filosofiei dreptului natural, John Finnis, care considera că bunurile care trebuie ocrotite de lege sunt viața, cunoaşterea, jocul, experiența estetică, sociabilitatea, rațiunea practică și religia7.

Spre deosebire de Platon, care a tratat problema dreptului natural în trecere, fără să clarifice unele dintre opiniile sale ${ }^{8}$, Aristotel oferă o concepție

7 Finnis, John, Natural Law and Natural Rights, Second Edition, Oxford: Oxford University Press, 2011, pp. 89-90. Finnis consideră că aceste bunuri sunt prezente în toate societăţile umane și țin de natura umană. Orice societate manifestă grijă pentru viața umană și concepe reguli care au drept scop stimularea procreerii unor noi vieți. Cunoașterea este o valoare care este folositoare pentru obținerea altor bunuri. Jocul poate fi întâlnit în toate societățile și din această cauză Finnis ajunge la concluzia că el este înrădăcinat în natura umană. Experiența estetică sub forma creației artistice poate fi întâlnită în toate societățile începând cu cele primitive. Sociabilitatea este un bun esențial pentru că contribuie la armonia socială atât la nivel individual, sub forma prieteniei, cât și la nivel internațional sub forma unor acorduri care mențin pacea. Familia, comunitatea de afaceri, comunitatea politică sunt forme de sociabilitate. Rațiunea practică sau morala constituie un factor de autocontrol al emoțiilor și reacțiilor care este util pentru societate. Această valoare nu se poate realiza decât în prezența libertății, rațiunii, integrității și autenticității. În sfârșit religia este un bun esențial pentru că implică relația dintre sine și ordinea cosmică, între uman și divin.

8 Ambiguitatea este des întâlnită în dialogurile platonice. De exemplu în prima parte a Republicii protagoniștii încearcă să de o definiție a justiției (sau dreptății) fără să ajungă la un consens iar Socrate propune să analizeze modul în care funcționează justiția într-un stat ideal pentru a clarifica problema. Totuși, în continuarea dialogului nu ne este oferită această definiție. Acest tip de abordare este întâlnit și în alte dialoguri platonice în care sunt propuse mai multe variante de definire a unor concepte fără să se ajungă la o sentință definitivă. 
clară şi sistematică în această privință. Concepția sa despre dreptul natural este formulată în cartea a V-a a Eticii nicomahice și în Retorica.

Aristotel analizează în cartea a V-a a Eticii nicomahice noțiunea de dreptate care, consideră el, are mai multe sensuri. Într-un prim sens este considerat nedrept cel care încalcă legea și încearcă sa aibă mai mult decât i se cuvine, nesocotind principiul egalității, iar drept cel care se conformează legilor şi respectă egalitatea. Nedreptatea se manifestă în sfera bunurilor pe care unii oameni încearcă să le obțină fără să aibă acest drept.

Dat fiind că cel care violează legea este un om nedrept iar cel ce o respectă e drept rezultă că într-un anume sens toate dispozițiile legale sunt drepte. Dreptatea e definită ca legalitate iar nedreptatea ca ilegalitate.

Aristotel consideră că există două tipuri de justiție: distributivă şi corectivă. Cea distributivă vizează distribuirea bunurilor materiale după valoare iar valoarea nu coincide cu egalitatea. Conflictele şi crimele încep atunci când cei egali nu împart şi nu posedă bunuri egale şi când cei inegali posedă și împart bunuri egale. Exegeții au numit acest principiu „principiul egalităţii proporționale” sau „al inegalităţii inegalilor”.

Dreptatea corectivă este cea care asigură corectitudinea raporturilor private. Aceasta e de două tipuri pentru că raporturile private pot avea caracter voluntar sau involuntar. Voluntare sunt de exemplu vânzarea, cumpărarea, împrumutul, depozitul, etc. Ele se numesc voluntare pentru că sunt rezultatul unui acord de voințe liber consimțit. Cele involuntare pot fi a) clandestine, ca furtul, adulterul, prostituția, etc şi b) acte de violență cum sunt omuciderea, jaful, sechestrarea de persoane etc.

În justiție contează numai faptele consideră Aristotel. Nu contează dacă un om de bine l-a jefuit pe un om de nimic sau un om de nimic l-a jefuit pe un om de bine, nici dacă un adulter a fost comis de un om de bine sau de 
un om de nimic, legea ia în considerare doar natura delictului, interesându-se doar dacă o parte a comis o nedreptatea iar alta a fost victima ei.

Aristotel consideră că dreptul este de natură politică pentru că elaborarea legilor și definirea nedreptății cad în sarcina cetății.

Aristotel împarte dreptul politic în două specii: dreptul natural și dreptul pozitiv. Dreptul natural este cel care își păstrează valabilitatea pretutindeni indiferent de opiniile care le suscită pentru că este impus de natura lucrurilor. Totuşi el acceptă faptul că într-o oarecare măsură și legile dreptului natural sunt schimbătoare pentru că și oamenii se schimbă de-a lungul timpului. Cauza validităţii dreptului natural este o necesitate morală şi logică. La dreptul natural se ajunge logic, prin raționament, plecând însăşi de la ideea de drept. Această idee a stat la baza doctrinei dreptului natural până în zilele noastre. Dreptul pozitiv provine dintr-o convenție, el fiind instituit de către comunitate. După cum formele de guvernământ diferă şi legile de drept pozitiv sunt diferite în fiecare comunitate.

În Retorica (1373b), Aristotel revine asupra subiectului dreptății şi a clasificării legilor: „Numesc lege, pe de o parte, legea proprie, pe de altă parte, legea comună; prin lege proprie înțeleg legea care, pentru fiecare popor în parte, a fost definită relativ la membrii săi, iar acest fel de lege este când nescrisă când scrisă; prin lege comună înțeleg legea care există natural”'. În continuare Aristotel invocă în sprijinul opiniei sale pasajul din Antigona analizat mai sus şi un fragment din Empedocle, care argumenta că a ucide o ființă însuflețită este o faptă nedreaptă, această interdicție fiind rezultatul legii tuturor „care se întinde peste tot cuprinsul vastului eter, care domnește

${ }_{9}^{9}$ Aristotel, Retorica, București: Editura IRI, 2004, p. 169. 
în depărtare peste pământul nemăsurat" ${ }^{\prime 10}$. Într-o secțiune ulterioară (1375 ab) stagiritul amintește din nou că legea scrisă este schimbătoare şi din această cauză, atunci când nu ne este favorabilă, putem recurge la legea comună (dreptul natural) care dăinuie dintotdeauna și nu se schimbă niciodată. Dreptul natural poate fi invocat, consideră Aristotel şi în situația unei antinomii, dacă legea este „contrară unei alte legi renumite, sau dacă, de asemenea, este contrară sieși”"11 precum şi în situația când legea este ambiguă.

Opiniile lui Aristotel despre dreptul natural sunt prezentate sumar și în Magna Moralia. Această carte este un tratat de etică atribuit în Antichitate şi Evul Mediu lui Aristotel dar a cărui origini sunt disputate în momentul de față. Unii exegeți consideră că un urmaș a lui Aristotel a elaborat cartea compilând unele prelegeri ale stagiritului. Această opinie pleacă de la analiza unui citat din carte care reproduce o frază din opera lui Chryssipus din Soli, filosof stoic care a a trăit între 279-206 î.e.n. ${ }^{12}$ Alți autori consideră că Magna Moralia a fost scrisă de Aristotel iar fragmentul respectiv a fost adăugat de copişti ulterior.

În Magna Moralia, este analizat din nou conceptul de drept natural iar autorul dezvoltă ideea, susținută în Etica Nicomahică, că legea naturală poate într-o oarecare măsură să se schimbe. În fragmentul 1194b - 1195a, este folosită o analogie pentru clarificarea problemei. Prin natură mâna dreaptă este mai îndemânatică și mai puternică iar mâna stângă este mai slabă. Dacă începem să folosim mâna stângă mai mult vom deveni ambidextri iar mâna stângă va deveni mai puternică. Însă chiar și în această situație între cele două

\footnotetext{
${ }^{10}$ Aristotel, ibidem.

${ }^{11}$ Aristotel, Retorica, p. 177.

${ }^{12}$ Allan, D.J., "Magna Moralia and Nichomachean Ethics" în The Journal of Hellenic Studies, November 1957, pp. 7-11.
} 
mâini va rămâne un decalaj, cea stângă fiind mai slabă decât dreapta. „Situația este aceeași în privința dreptului natural; atunci când există schimbări în modul de folosire a lui (care este modul în care îl aplicăm în practică) atunci aceste schimbări nu transformă legea originală într-o lege nenaturală. Ea rămâne ceea ce a fost.” Spre deosebire de opinia din Etica nicomahică, în care Aristotel considera că uneori dreptul natural se schimbă pentru că şi natura umană evoluează, în Magna moralia se consideră că schimbările care afectează dreptul natural țin mai degrabă de modul în care sunt puse în practică axiomele naturale.

După moartea lui Aristotel, în afară de filosofii școlii peripatetice, teoria dreptului natural a fost preluată de stoici. Stoicii greci erau panteiști și considerau că „Legea creată de om nu este altceva decât expresia unei legi naturale, eterne, ce se naște din logos-ul ce plănuiește toate lucrurile, care logos, în virtutea propriei raționalități, stabilește ce e bine și ce e rău, adică impune sarcini și opreliști” ${ }^{3}$. O idee specifică stoicismului a fost cea a egalității naturale a oamenilor. Această idee a avut drept consecință faptul că mulți filosofi stoici au insistat asupra egalității cetățenilor în fața legii. Stoicismul a fost filosofia care a fost preferată de către romani fiind mai potrivită cu spiritul lor practic, cu etica militară și cu forma de guvernare republicană. Odată cu stoicismul a fost preluată și filosofia dreptului natural.

Cicero, cel mai important filosof roman interesat de filosofia dreptului, a fost influențat de filosofia stoicilor și de dialogurile platonice. În lucrările sale teoria dreptului natural ocupă un loc de frunte. Cicero considera că libertatea individului nu se poate realiza decât într-o republică constituțională unde domină persuasiunea și nu coerciția. Însă pentru a o realiza este nevoie

\footnotetext{
13 Reale, Giovanni, Istoria filosofiei antice, vol. 5: Cinismul, epicureismul și stoicismul, Târgu-
} Lăpuş: Editura Galaxia Gutenberg, 2016, p. 445. 
de oameni buni care să se coalizeze pentru a impune dreptatea. Legea trebuie să fie în acord cu natura scrie el în De Re Publica. „Legea adevărată este rațiunea dreaptă în conformitatea cu natura, universală, neschimbată, eternă, care ne oprește să facem rău (...) Această lege nu poate fi contrazisă de nici o altă lege, şi nu se poate nici deroga de la ea, nici nu poate fi abrogată. Nici senatul și nici poporul nu ne poate da permisiunea să nu ne supunem acestei legi universale a justiției” ${ }^{14}$. Vedem aici o continuare a doctrinei dreptului natural formulată de Aristotel.

Cicero consideră că ordinea socială și nu natura este sursa inegalității. Natura ne comandă să ne acordăm respect egal datorită faptului că suntem descendenții aceleiași comunități umane. Statul trebuie să fie o comunitate etică iar legile rezultatul acordului comunităţii.

În De legibus, Cicero reia aceste idei dezvoltându-le. Natura este sursa legilor la care individul ajunge cu ajutorul rațiunii. Originea dreptăţii se găsește în lege pentru că aceasta este o forță a naturii. Legea naturală este diferită de legile pozitive, temporare şi create de om. Legea naturală există chiar dacă nu este recunoscută de dreptul pozitiv. Chiar dacă nu exista o lege împotriva violului pe vremea lui Tarquinius, fiul acestuia a încălcat legea naturală atunci când a violat-o pe Lucreția.

Legile pozitive pot fi promulgate și de tirani sau grupuri dornice să-și impună puterea. Dar în acest caz societatea va sesiza faptul că legile sunt nedrepte. Dacă legea ar permite adulterul sau falsificarea testamenelor opinia publică nu ar accepta o astfel de lege.

Legile au fost create pentru a garanta siguranța cetățenilor, conservarea statului, liniștea și fericirea ființei umane. De aceea legile care au

\footnotetext{
${ }^{14}$ A se vedea Cicero, Marcus Tullius, De Re Publica, cartea a 3-a cap. 22.
} 
un rezultat contrar nu pot fi numite legi și întotdeauna vor sfârși prin a fi înlăturate de comunitate.

\section{Filosofia dreptului natural în Evul Mediu : Sfântul Augustin,} Albertus Magnus, Toma din Aquino, școala de la Salamanca.

Zorii Evului mediu au fost dominați de gândirea Sfântului Augustin (Aurelius Augustinus). Filosofia lui Augustin din Hippo a fost influențată de Platon şi Cicero. Teoria platonică a lumii perfecte a ideilor ${ }^{15}$ cărora le corespund în realitate manifestări imperfecte ale acestor idei a fost combinată cu teologia creștină ${ }^{16}$. Cicero a fost o altă sursă importantă în special în domeniul filosofiei dreptului. Augustin mărturisea că a decis să studieze filosofia după ce a citit dialogul Hortensius al lui Cicero.

În Confesiuni, Augustin consideră că Dumnezeu l-a creat pe om ca pe o ființă morală. Omul poartă în el urmele creației ceea ce înseamnă că există relații permanente între om şi Dumnezeu. Nu din întâmplare caută omul fericirea. Această căutare este o urmare a sentimentului său de incompletitudine. El găsește fericirea numai în Dumnezeu.

Relația dintre om și Dumnezeu este guvernată de liberul arbitru. Omul e liber să se îndrepte spre Dumnezeu sau să se îndepărteze de el. Răul sau păcatul sunt rezultatul voinței pentru că omul poate folosi liberul arbitru

\footnotetext{
15 Platon a folosit alternativ cu termenul de idee cel de „forme”.

16 Pentru o analiză a influenței lui Platon asupra filosofiei lui Augustin vezi Biemiller, Marc, ”Augustine and Plato: Clarifying Misconceptions" în Aporia, nr2/2019, pp. 33-43.
} 
ca să aleagă greșit iar atunci când știe care este alegerea corectă poate să nu aibă puterea spirituală de a face binele.

Voința politică este supusă acelorași legi ca și voința individuală. Toți oamenii recunosc adevărul şi îl consideră lege naturală sau drept natural. Dreptul natural este impărtășirea adevărului lui Dumnezeu sau a legii sale eterne. Datorită faptului că legea naturală este instituită de voința divină, Dumnezeu pedepsește încălcarea ei. Statul este autonom în alcătuirea legilor însă legile temporale trebuie să fie în acord cu legea eternă.

Dacă legile statului nu sunt în armonie cu legea naturală și cu justiţia eternă atunci ele nu au caracter de legi. Această idee se regăsește la majoritatea adepților dreptului natural. La fel și ideea că dreptul natural poate fi descoperit prin introspecție. Legile temporale, care au scopul de a menține ordinea în societate, trebuie să fie deci morale. Justiția este legată direct sau indirect de morala creștină. Legea pozitivă nu pedepsește păcatul ci violarea ordinii sociale. Ea previne răul însă nu îi face pe oameni mai buni. Mai buni devin doar cei care respectă legea naturală.

În Cetatea lui Dumnezeu, Augustin îi împarte pe oameni în două grupuri - cei care îl iubesc pe Dumnezeu și cei ce se iubesc pe sine. Aceste grupuri formează societăți diferite pe care Augustin le numește Cetatea lui Dumnezeu și Cetatea lumii. Cele două cetăţi nu sunt identice cu biserica și statul. Cei care se iubesc pe sine pot fi găsiți și în rândurile bisericii. Augustin dezvoltă o adevărată filosofie a istoriei plecând de la ideea conflictului dintre cele două cetăți.

Justiția nu este văzută ca o relație între oameni ci ca o relație a omului cu Dumnezeu. Chiar dacă o infracțiune pare la prima vedere a fi o greșeală față de un alt om de fapt ea este în primul rând o încălcare a legii divine care ne spune să ne iubim aproapele. 
Filosofia lui Augustin este inspirată de filosofia lui Platon. Paralela dintre dreptul natural care este perfect și dreptul pozitiv imperfect este o reflectare a modelului platonic a lumii perfecte a ideilor și a lumii reale care reprezintă o variantă imperfectă a acesteia.

După ce creștinismul a devenit religia oficială atât pe teritoriul fostului Imperiu Roman de Apus cât și pe teritoriul bizantin, creștinii au declanșat o activitate de distrugere a cărților filosofilor antici. În primele secole ale Evului Mediu au fost distruse majoritatea operelor celor mai importanți filosofi greci şi romani ${ }^{17}$. Din acest autodafé au scăpat doar câțiva filosofi agreați de biserică şi considerați precursori ai gândirii creștine. Unele opere filosofice antice au supraviețuit în bibliotecile din Orientul Mijlociu. Ele au putut fi consultate de către teologii creștini în bibliotecile din Spania ocupată de mauri. După ce au fost traduse în latină au revenit în circulaţie contribuind apoi la renașerea culturală europeană.

După o primă perioadă a Evului Mediu dominată de neoplatoniști Europa l-a redescoperit pe Aristotel. O parte din operele lui Aristotel au fost traduse în latină de către Gerard din Cremona, James din Veneția şi William din Moerbeke ${ }^{18}$. Aristotel i-a fascinat pe europeni pentru că tratatele sale abordau diverse domenii care fuseseră uitate în perioada Evului Mediu întunecat. Lucrările sale de biologie, fizică, meteorologie, psihologie, economie, politologie, etică etc., au stat la baza dezvoltării științelor din perioada Renașterii ${ }^{19}$. Redescoperirea lui Aristotel a dus la un conflict între

\footnotetext{
17 Pentru detalii vezi Nixey, Catherine, Epoca întunecării, București: Humanitas, 2019. 18 Toma din Aquino a citit operele lui Aristotel traduse de William din Moerbeke. 19 Singura operă cunoscută a lui Aristotel în timpul Evului Mediu a fost Organonul, tradus în latină în secolul al VI-lea.
} 
adepții lui Augustin și ai platonismului și adepții lui Toma din Aquino și ai lui Aristotel.

Primul autor care a tratat problema dreptului natural plecând de la Aristotel a fost Albertus Magnus, teolog, filosof, călugăr dominican și profesor la Universitatea din Paris. Albertus Magnus a fost primul autor medieval care a analizat toate operele cunoscute ale lui Aristotel, popularizând astfel ideile sale. Concepția sa privind filosofia dreptului a fost dezvoltată în De Bono și în Comentarïle la Etica Nicomahică.

Albertus Magnus considera că dreptul natural era un habitus ${ }^{20}$ înnăscut care a fost imprimat de divinitate în sufletul uman. Apelând la acest habitus oamenii pot descoperi principiile morale fundamentale care sunt sursa binelui și răului. De Bono se înspiră din Etica Nicomahică fiind, la fel ca și aceasta, un tratat de etică ce pune pe primul plan virtuțile. Cărțile II-IV ale tratatului analizează trei virtuți pe care autorul le consideră esențiale: prudența, cumpătarea și tăria morală. Cartea a V-a analizează virtutea justiției și este divizată în două părți: prima este dedicată dreptului natural (ius naturale) iar a doua legii naturale (lex naturalis) ${ }^{21}$. Impreună, dreptul natural şi legea naturală formează virtutea justiţiei. Albertus Magnus citează opiniile unor filosofi anteriori, Aristotel, Cicero, Gratian, Augustin, William din Auxerre, etc și ajunge la concluzia că opiniile lui Aristotel și Cicero sunt cele mai temeinice. El este de părere că dreptul natural, implantat în sufletul uman de divinitate, servește ca prim principiu al dreptului - prima principia iuris,

\footnotetext{
20 Un habitus este, conform concepției teologice medievale, o calitate sau trăsătură care ghidează ființa umană înzestrată cu liber arbitru în acțiunile sale morale, ajutând-o să aleagă binele și să evite răul.

21 Stanley Cunningham subliniază faptul că Albertus Magnus este primul autor care face distincția între noțiunile de „drept - ius” și „lege - lex” care, până la el, erau folosite alternativ fiind considerate sinonime.
} 
fiind totodată și un prim principiu al moralei. Autorul compara principiile dreptului natural cu principiile logicii. La fel cum principiile identității, noncontradicției și terțului exclus ne ajută să gândim corect și ne ghidează spre adevăr la fel și principiile dreptului natural ne ajută să luăm decizii morale. Aceste principii ne ghidează acțiunile în efortul nostru de a duce o viață virtuoasă. Una dintre legile naturale cele mai importante este „regula de aur”, pe care o întâlnim în Evanghelia după Matei 7:12 - „Fă altora ce ai dori să ți se facă și ție"22. La naștere omul deține doar axiomele dreptului natural implantate de divinitate iar în rest intelectul său este o tabula rasa. De-a lungul timpului omul acumulează diverse alte cunoștințe prin intermediul simțurilor şi experienței de viață şi le dă acestora o semnificație morală prin raportare la principiile dreptului natural. Această raportare se face printr-un mecanism silogistic. Legile naturale sunt legi ale rațiunii și datorită faptului că omul este singurul animal rațional nu le întâlnim la alte animale.

În cartea a V-a a lui De Bono, Albertus Magnus face distincția între drept și lege, considerând că dreptul este genul iar legea este specia. Dreptul este o realitate abstractă pe când legea este „drept scris”. Dreptul conține principii generale pe când legea constă în aplicarea acestor principii în situații speciale, de obicei prin formularea unor interdicții cu privire la comportamentele umane, a unor obligații sau reguli. Scopul legii este de a-l ghida pe om spre perfecțiunea morală.

Toma din Aquino a fost cel mai important discipol al lui Albertus Magnus. El l-a cunoscut pe acesta în 1245, la Universitatea din Paris, unde fusese trimis la studii de către Ordinul Dominican din care făcea parte. Între maestru şi tânărul discipol s-au dezvoltat relații de prietenie iar atunci când

\footnotetext{
22. Această perspectivă a fost preluată în secolul XX de către Robert P. George care pune la baza filosofiei sale juridice principiul paulin sau regula de aur.
} 
Albertus Magnus a fost trimis să predea teologia la Cologne, în 1248, Toma la urmat deși între timp primise oferta de a fi abatele mănăstirii din Monte Casino. În 1252 s-a întors la Paris unde s-a înscris la studiile pentru masteratul în teologie. În această perioadă a fost angajat ca lector universitar şi a scris primele sale cărți de teologie și filosofie.

Datorită operei sale impresionante, atât ca volum cât și ca valoare ideatică, Toma din Aquino este cel mai important reprezentant al filosofiei dreptului natural clasic. El a fost principala sursa de inspirație pentru școala contemporană a dreptului natural. Unii reprezentanți ai acesteia au fost chiar denumiți neotomiști. Contribuția sa esențială la dezvoltarea doctrinei catolice a fost recompensată prin canonizarea sa și prin titlul de Doctor al Bisericii Catolice $^{23}$. Toma din Aquino a fost un adept al filosofiei lui Aristotel, pe care îl considera o autoritatea supremă în toate domeniile abordate de stagirit. Admirația sa pentru Aristotel îl face pe Toma să îl denumească pe acesta, atunci când îi citează unele idei „filosoful” fără să îi mai amintească numele. Înfluența lui Toma din Aquino i-a determinat pe teologii catolici să abandoneze platonismul și să devină adepți ai lui Aristotel. În timpul vieții sale între platoniști și aristotelieni au avut loc numeroase dezbateri și controverse. În deceniile care au urmat morții lui Toma, influența sa a făcut ca platonismul să cadă în dizgraţie fiind învins aproape definitiv de aristotelism.

Toma din Aquino și-a expus ideile despre drept în manieră sistematizată în Summa Theologica, o operă monumentală în care analiza doctrina catolică. Lucrarea este structurată ca un catehism cu întrebări la care sunt prezentate răspunsuri. De multe ori în secțiunea dedicată răspunsului

23 În lucrările de teologie care îl citează întâlnim și titulaturile de „Doctor Angelicus” sau „Doctor Communis”. 
Toma prezintă şi argumentele altor filosofi şi în special ale adversarilor şi le combate înainte de a formula soluția sa.

O parte considerabilă a tratatului este dedicată concepției despre drept. În volumul al doilea Toma face distincția între legea eternă, legea naturală, legea oamenilor și legea pozitivă divină ${ }^{24}$.

Legea eternă este planul lui Dumnezeu cu privire la ordinea lucrurilor din univers de la început până la sfârșitul lor.

Legea naturală constă din porțiuni ale legii eterne care se referă la om. Chiar dacă omul nu poate cunoaşte legea eternă el poate ajunge să cunoască legea naturală prin raționament și poate distinge pe această cale binele de rău. Legea naturală este o participare a omului la legea eternă.

Legea omenească este cea emisă de guverne și trebuie să fie derivată din legea naturală.

Legea divină este cea care îl indreaptă pe om spre scopul său supranatural. Dacă celelalte legi au drept scop fericirea omului pe pământ, legea divină are drept scop cunoaşterea lui Dumnezeu şi o găsim prin studierea Bibliei.

În răspunsul la Întrebarea 90 despre promulgarea legii Aquino scrie că „promulgarea nu este esențială pentru o lege. Pentru că legea naturală, înainte de toate, are caracter de lege. Dar legea naturală nu are nevoie de promulgare (...) Legea naturală este promulgată prin faptul că Dumnezeu a

\footnotetext{
24 Concepția sa despre tipurile de drept a fost dezvoltată în întrebările 90-108, din partea întâi a celui de-al doilea volum, în capitolul intitulat „Tratat despre drept”. Acesta nu este însă singura secțiune dedicată filosofiei dreptului. În partea a treia a Summei Teologice se revine atât asupra definiției dreptului (Q 57) cât și asupra unui număr de probleme juridice. Aici Toma analizează din punct de vedere al dreptului natural și un număr de infracțiuni (omorul, furtul, tâlhăria, acţiunile violente, insulta, calomnia etc).
} 
introdus-o în mintea omului pentru a fi cunoscută de el în mod natural"25. Omul are înclinaţii naturale de a face bine însă aceste înclinații trebuiesc să fie cultivate şi exersate. El trebuie să învețe să îşi controleze poftele şi pasiunile pentru a deveni o ființă mai bună. Datorită faptului că legea naturală a fost implantată în mintea omului putem să o cunoaștem cu ajutorul rațiunii. Întrebarea 94 este dedicată legii naturale. Preceptele legii naturale se referă la probleme practice și sunt evidente prin ele însele având rol de axiomă în relație cu toate celelalate precepte juridice. Cel mai important principiu prevede că trebuie să facem bine și să evităm să facem rău. Dealtfel, consideră autorul, omul are o înclinație naturală de a fi bun și de a conserva viața umană. Alături de acest instinct de conservare a speciei omul mai posedă, împreună cu alte animale, înstinctul sexual, cel de a oferi educație urmaşilor, etc. În al treilea rând omul are dorința dea trăi în societate și evită să îi supere pe cei alături de care trăiește.

Toma din Aquino consideră că legea naturală poate fi schimbată numai în două moduri: prin adăugarea unor principii noi care să aducă beneficii vieții umane şi prin schimbarea unor principii secundare, în cazuri rare, dacă este necesar. Dreptul natural nu poate fi cunoscut deci prin studierea Bibliei ci prin căutarea cu ajutorul rațiunii a principiilor care să contribuie la perpetuarea și bunăstarea speciei și societății.

Toma din Aquino susținea că scopul legii pozitive, sau umane cum o denumește el, este de a promova în rândul comunității virtuțile și de a realiza binele comun. Legile umane pot fi dreapte sau nedrepte. Cele drepte derivă din legea eternă. Legile nedrepte pot fi de două feluri: legi care sunt contrare binelui comun şi intereselor comunității şi legi care se opun binelui divin şi

${ }^{25}$ Aquinas, Thomas, Summa Theologica, Part I-II, Q. 90, art.4. 
legii divine. Din această categorie ar face parte de exemplu o lege care ar introduce idolatria. Legile contrare intereselor comunităţii pot fi legi care impun sarcini inegale membrilor comunității sau care au drept scop realizarea intereselor conducătorului, interese egoiste și contrare celor ale comunității. La fel ca şi Augustin, Toma consideră că dacă legea pozitivă încalcă preceptele legii naturale ea poate fi declarată nedreaptă. Suveranul nu are dreptul să emită orice lege pentru supușii săi ci numai legi în concordanță cu legea naturală, adică legi care să servească binelui comun pentru societate. Legea adevărată există şi în oameni pentru că dacă este în concordanță cu principiile naturale implantate de Dumnezeu în rațiunea umană ea va fi recunoscută şi acceptată.

Legile umane pot deriva din cele naturale în două moduri. Pe de o parte ele pot fi desprinse prin metode silogistice, ca niște concluzii derivate din premise. Pe de altă parte ele pot fi desprinse prin determinarea principiilor generale ale dreptului natural şi aplicarea acestora în cazuri particulare.

Spre deosebire de Augustin, care făcea diferență între Cetatea lui Dumnezeu și Cetatea lumii, şi o considera pe aceasta din urmă o expresie a slăbiciunii umane și a păcatului, Toma consideră că originea statului se află în natura umană. Omul, ca animal social, are o tendință naturală de a alcătui state. Statul a apărut din voința lui Dumnezeu și are funcția de a ghida natura umană pentru obținerea binelui social. Chiar dacă statul este în mare măsură autonom el este subordonat bisericii. Această subordonare se manifestă prin faptul că biserica încearcă să ghideze societatea pentru ca aceasta să atingă starea de uniune spirituală cu Dumnezeu. Suveranul trebuie deci să emită doar acele legi care nu pericliteaza acest scop ultim. Libertatea statului este 
limitată și de cerința ca legile să fie în concordanță cu legea naturală, adică să fie în folosul comunității.

Filosofii și teologii de la sfârşitul Evului Mediu nu au adus contribuţii originale la teoria dreptului natural, mulțumindu-se să repete ideile tomiste. O excepție o fac filosofii și teologii din Școala de la Salamanca. Expresia „Școala de la Salamanca” este folosită pentru a desemna un grup de teologi și jurişti care au predat la Universitatea din Salamanca sau au avut relații cu această universitate precum și un grup de teologi și juriști portughezi, care au activat în Universitatea din Coimbra și au fost influențați de intelectualii din Salamanca. Cei mai importanți autori din Salamanca au fost călugării dominicani Francisco de Vitoria, fondatorul școlii, Juan de Segovia, Alfonso Tostado de Madrigal, Bartolomé de las Casas și Domingo de Soto. Teologii din Coimbra făceau parte din Ordinul Iezuit. Cei mai importanți au fost Louis de Molina, Francisco Suárez şi Giovanni Botero.

Membrii școlii de la Salamanca au încercat să adapteze filosofia lui Toma din Aquino la cerințele vremii și să o aplice la o serie de probleme contemporane cum erau cele legate de colonizarea Americii, evanghelizarea populațiilor indigene și problema legalităţii sclaviei. Ei au încercat să aplice principiile dreptului natural în domeniul dreptului internațional, al drepturilor omului și a dreptului războiului. Importanța Şcolii de la Salamanca este dată de faptul că o parte dintre membrii ei au preluat critic filosofia lui Toma din Aquino, polemizând uneori cu el și considerând că unele dintre tezele sale sunt greșite. De pildă, în De Legibus, Francisco Suárez susține că prin conceptul de lege se înțelege o regulă care guvernează comportamentul unor ființe capabile să ia decizii libere. Plecând de la această definiție el contestă conceptul de „lege eternă” al lui Toma din Aquino. Aceasta poate fi considerată lege doar într-un sens metaforic pentru că nu 
permite o alegere liberă a unui tip de comportament și deci nu poate sta la baza celorlalte legi. Pentru Suárez dreptul natural este vocea rațiunii care îl influențează pe om prin intermediul conștiinței. Unii dintre membrii Școlii de la Salamanca au fost preocupați de problema proprietăţii private ${ }^{26}$. Proprietatea privată nu era considerată de primii reprezentanți ai acestei școli ca ținând de dreptul natural ci doar de dreptul pozitiv și deci nu era considerată un drept absolut. Totuși reprezentanții târzii ai Școlii de la Salamanca au ajuns la concluzia că proprietatea privată ține de ius gentium și derivă din principiile generale ale dreptului natural. Domingo de Soto și Luis de Molina considerau că proprietatea comună îi face pe oameni neglijenți față de bunurile deținute în comun și acest lucru dezavantajează comunitatea respectivă. Din această cauză proprietatea privată trebuie acceptată ca un drept necesar. Dreptul de proprietate privată nu era considerat contrar principiilor dreptului natural pentru că el furniza motivație pentru muncă, favoriza pacea socială, comerțul, o bună utilizare a resurselor și, în consecință, promova binele comun.

În secțiunile dedicate furtului și tâlhăriei Toma din Aquino considera că acestea sunt justificate dacă făptuitorul e sărac și le săvârșește pentru a supraviețui. Reprezentanții Școlii de la Salamanca nu sunt în totalitate de acord cu această opinie. Ei considerau că deși în situaţii de necesitate o persoană poate folosi bunurile altuia această faptă nu constituie un transfer al dreptului de proprietate ci doar un împrumut, făptuitorul fiind obligat să restituie bunurile după ce starea de necesitate a încetat. Martín de Azpilcueta menționa că nici o persoană nu este obligată să doneze ceva cuiva care se află

${ }^{26}$ Alves, Andre A.; Moreira, Jose M., The Salamanca School, New York: Continuum, 2010, pp. 65-71. 
în nevoie pentru că obligația de a-ți ajuta aproapele nu ține de drept ci de caritate.

Primii reprezentanți ai școlii au considerat că împrumuturile bancare și cămătăria nu trebuie acceptate, preluând opinia tomistă și poziția oficială a Bisericii Catolice. Reprezentanții târzii ai școlii și-au nuanțat însă poziția acceptând băncile și împrumuturile bancare cu condiția ca dobânzile să nu fie excesiv de mari. Molina menționa că deși băncile trebuie acceptate ca instituții legitime este important ca bancherii să nu folosească depozitele clienților pentru a face investiții riscante pentru că ei sunt responsabili de siguranța acestor depozite.

Preluând ideile lui Aristotel și Toma din Aquino, membrii Şcolii de la Salamanca acceptau legitimitatea sclaviei. Totuși unii dintre ei susțineau că în virtutea faptului că sunt oameni până și sclavii au unele drepturi. În De iustitia et iure, Molina menționa că un sclav are drept de proprietate asupra bunurilor câștigate la un joc de noroc de la stăpânul său. El oferea şi alte exemple ale drepturilor sclavilor, cum ar fi dreptul de a nu fi vătămați corporal dacă nu au făcut nimic care să justifice pedeapsa.

Francisco de Vitoria este considerat unul dintre părinţii dreptului internațional modern. În De Indis și De iure beli, Vitoria susținea că amerindienii au drept de proprietate asupra terenurilor pe care locuiesc și nu accepta deposedarea lor de către coloniștii europeni. Războiul împotriva indienilor era considerat un război injust. El considera că sclavia nu ține de dreptul natural ci este o instituție de drept pozitiv sau civil. În De iure beli, Francisco de Vitoria analiza problema războiului just și injust. El opina că nu poate fi justificat decât războiul pentru autoapărare. Diferențele de religie sau dorința de a mări imperiul nu sunt motive justificate pentru declanşarea unui război. 
Încercarea Școlii de la Salamanca de a moderniza filosofia dreptului natural nu a împiedicat intrarea acesteia în desuetudine. Dreptul natural a mai fost invocat și de unii filosofi din perioada Renașterii sau din perioada modernă însă sensul acestei sintagme nu era acelaşi. Principiile dreptului naturale erau considerat simple cerințe morale care nu îl obligă pe legiuitor şi nu justifică încălcarea legii.

\section{Bibliografie}

Adams, David M., Philosophical Problems in the Law, Boston: Wadsworth Cengage Learning, 2012.

Alberti Magni, Opera omnia: De bono, Vol. 28, Munster: Aschendorff, 1951. Alves, Andre A.; Moreira, Jose M., The Salamanca School, New York: Continuum, 2010.

Aquinas, Saint Thomas, Summa Theologica: Complete Edition, New York: Catholic Way Publishing, 2014.

Aristotel, Etica nicomahică, București: Editura IRI, 1998.

Aristotle, Magna Moralia, Miami: HardPress Publishing, 2012.

Burns, Tony, Aristotle and natural law, London: Continuum International Publishing Group, 2011.

Cicero, The Republic and The Laws, Oxford: Oxford University Press, 2009. Citron, Rodger D., "The Nuremberg Trials and American Jurisprudence: The Decline of Legal Realism. The revival of Natural Law, and the Development of Legal Process Theory" în Michigan State Law Review, 2006, pp. 385-410.

Cunningham, Stanley B., "Albertus Magnus on Natural Law" în Journal of the History of Ideas, nr. 4/1967, pp. 480-485. 
Finnis, John, Aquinas: Moral, Political, and Legal Theory, Oxford: Oxford University Press, 1998

Finnis, John, Natural law and natural rights, Second Edition, Oxford: Oxford University Press, 2011.

Bunge, Kirstin; Fuchs, Marko J.; Simmermacher, Danaë; Spindler, Anselm (eds.), The Concept of Law (lex) in the Moral and Political Thought of the "School of Salamanca", Leiden: Brill, 2016.

Morrison, Wayne, Jurisprudence: From the Greeks to Post-Modernists, London: Routledge, 2016.

O'Connor, D. J., Aquinas and Natural Law, London: Macmillan Education, 1967.

Plato, The Laws, Harmondsworth: Penguin Books, 1970.

Platon, Opere, vol I, București: Editura Ştiințifică şi Enciclopedică, 1975.

Platon, Opere, vol. V: Republica, București: Editura Științifică și Enciclopedică, 1986.

Reale, Giovanni, Istoria filosofiei antice, vol 3: Platon și Academia antică, Târgu Lăpuș: Galaxia Gutenberg, 2009.

Reale, Giovanni, Istoria filosofiei antice, vol. 5: Cinismul, epicureismul și stoicismul, Târgu-Lăpuș: Editura Galaxia Gutenberg, 2016.

George, Robert P., In defense of natural law, Oxford: Clarendon Press, 2001. Saint Augustine, The City of God: Books I-VII, Washington D.C.:The Catholic Univversity of America Press, 2008.

Saint Augustine, The City of God: Books VIII-XVI, Washington D.C.:The Catholic Univversity of America Press, 2008.

Sophocles, Antigone, Oxford: Oxford University Press, 2003. 
Tierney, Brian, The Ideea of Natural Rights: Studies on Natural Rights, Natural Law, and Church Law 1150-1625, Grand Rapids: William B. Eerdmans Publishing Company, 2001. 